\title{
MEDIA PEMBELAJARAN BERBASIS GOOGLE CLASSROOM
}

\author{
Oleh : Adhetya kurniawan, Gilang Prabowo, Thariq Falahudin, Program Studi \\ Pendidikan Teknik Otomotif, Fakultas Teknik,Universitas Negeri \\ Semarang, Gunungpati. \\ Email : adiet@mail.unnes.ac.id
}

\section{ABSTRAK}

Pendidikan tinggi dalam gerakan Literasi baru harus menguasai literasi data, literasi teknologi, literasi bahasa dan literasi manusia di era Revolusi Industri 4.0. Oleh sebab itu, diperlukan media pembelajaran bentuk sebagai penerapan teknologi digital untuk meningkatkan perkembangan teknologi pembelajaran sesuai perkembangan revolusi industri 4.0. Selain itu, dunia pendidikan yang menggunakan kertas dalam media pembelajaran, perangkat pembelajaran, administrasi pendidikan, dan instrumen evaluasi sebaiknya sudah mulai beralih pada sistem nirkertas dalam penyelenggaraan pembelajaran. Pengembangan media pembelajaran berbasis google classroom menjadi alternatif solusi permasalahan penggunaan kertas dan tuntutan revolusi industri $4.0 \mathrm{di}$ dunia pendidikan.

Tujuan penelitian ini adalah pengembangan media pembelajaran berbasis google classroom pada mata kuliah teknik tenaga listrik. Penelitian ini dikembangkan dengan metode waterfall. Sistem dikembangkan melalui tahapan analisis kebutuhan, desain ujian, implementasi, uji coba, dan perawatan.

Hasil pembuatan media pembelajaran dengan google classroom secara keseluruhan dapat digunakan dengan baik, pada bagian menu, sub menu, tampilan soal, dan pemberian sekor berfungsi dengan baik. Hal ini berarti bahwa media media pembelajaran google classroom ini dapat dipakai dalam pembelajaran di mata kuliah teori lainnya.

Kata kunci : Media pembelajaran, google classroom

\section{PENDAHULUAN}

Proses pembelajaran merupakan alat bantu transfer ilmu dan pengeatahuan dari pendidik kepada peserta didik yang dapat membantu pembelajaran terasa lebih menarik. Untuk melengkapi dan membantu para pendidik dalam menyampaikan informasi, media pembelajaran perlu disusun dengan baik dengan menggunakan media modern di dalam pembelajaran. Dengan menggunakan media diharapkan terjadi interaksi antara pendidik dengan peserta didik dapat dilaksanakan secara maksimal sehingga dapat 
mencapai hasil belajar yang sesuai dengan tujuan. Para pendidik sangat disarankan untuk para guru untuk memilih dan menggunakan media dengan tepat baik menggunakan kertas maupun nirkertas.

Media pembelajaran online google classroom merupakan media nirkertas yang mendukung kelestarian lingkungan hutan. Namun, sesuai perkembangan revolusi industri 4.0, google classroom juga memiliki peran mengikuti kebutuhan pendidikan yang sesuai perkembangan teknologi terkini. Deputi Teknologi Agroindustri dan Bioteknologi (TAB) BPPT Soni Solistia Wirawan dalam siaran pers BPPT (2019) menyatakan bahwa, dosen tidak hanya mengajarkan ilmu atau kompetensi kepada mahasiswa, tapi juga memberi pengalaman dan pandangan inovatif sehingga mahasiswa dapat adaptif saat bekerja. Lebih lanjut, Pendidikan tinggi dalam gerakan Literasi baru harus menguasai literasi data, literasi teknologi, literasi bahasa dan literasi manusia di era Revolusi Industri 4.0. Hal tersebut menunjukkan bahwa media pembelajaran online merupakan salah satu yang diperlukan pembelajaran di kampus untuk meningkatkan perkembangan teknologi pembelajaran sesuai perkembangan revolusi industri 4.0.

Tantangan lembaga penyelenggara pendidikan dan pembelajaran pada tahun akan datang adalah untuk memotivasi orang untuk menggunakan media secara efektif dan efisien (Hendry, 2019). Media tidak hanya akan mengubah cara pebelajar, tetapi juga akan mengubah cara pendidik dan pengajar berpikir tentang mengajar dan belajar. Lebih lanjut, manusia yang bekerja dengan teknologi pendidikan dengan kreatifitas memiliki semangat membuat inovasi yang diterapkan ke dalam media pembelajaran di lingkungan pembelajarannya. Media pembelajaran online digunakan oleh pendidik sebagai sarana transfer materi secara umum menggunakan teknologi sesuai revolusi industri 4.0 dan menerapkan nirkertas.

Kertas memang sangat diperlukan dalam kehidupan manusia salah satunya sebagai bahan untuk pembuatan uang, pembuatan buku dan tisu yang paling 
banyak digunakan saat ini. Hampir seluruh kegiatan manusia seperti pendidikan, pekerjaan, komunikasi, kesehatan serta perbankan umumnya sangat membutuhkan kertas. Namun, sebagai manusia haruslah bijak dalam menggunakan kertas serta dianjurkan untuk menghemat penggunaan kertas. Seperti menggunakannya untuk hal-hal yang penting, tidak boros ataupun membuang-buang kertas untuk hal yang tidak berguna.

Dunia pendidikan terutama di kampus juga memiliki peran penting dalam kebijakan pengelolaan kertas. Hal itu dapat dilakukan dengan mengarahkan seluruh proses pembelajaran dengan budaya nirkertas. Budaya nirkertas dilakukan dapat menurunkan kebutuhan kertas dalam dunia pendidikan yang sangat besar terutama dalam pembuatan perangkat pembelajaran.

Media pembelajaran nirkertas sangat tepat dijadikan sebagai bidang garapan konservasi lingkungan. Pembelajaran e-learning, media power point, dan media pembelajaran internet maupun online mendorong peningkatan budaya nirkertas. Oleh sebab itu, ujian yang mendukung konservasi lingkungan sebaiknya sudah tidak perlu menggunakan kertas sebagai media ujian. Hal ini dapat diwujudkan salah satunya dengan cara ujian dengan bantuan google classroom. Peserta ujian dapat mengakses google classroom menggunakan komputer dalam program yang perambah internet explore, google chrome, dan perambah lain.

Google classroom dapat membantu mengelola ujian dan penilaian dengan baik sampai dengan pensekoran. Hal ini disebabkan google classroom membantu menampilkan jawaban peserta ujian dengan kunci jawaban yang sudah disiapkan oleh pembuat soal sehingga menghemat waktu, pikiran dan terutama tidak memerlukan kertas. Pengelolaan waktu ujian juga dapat diatur otomatis sesuai kebutuhan pembuat soal sehingga saat waktu ujian habis, maka secara otomatis peserta ujian sudah tidak dapat mengerjakan lagi dan sistem terkunci. Hal tersebut menarik untuk peserta dan memotivasi dalam belajar, sesuai pendapat aplikasi Google dapat diterima oleh siswa dan memfasilitasi peningkatan dalam pencapaian prestasi belajar siswa, (abdullah: 2019). Lebih lanjut, Eros (2003) menyatakan Siswa yang belajar dengan sistem online (Mallard) berkinerja lebih Jurnal Pendidikan Teknik Otomotif_Universitas Muhammadiyah Purworejo 
baik secara signifikan pada kriteria prestasi daripada siswa dengan pembelajaran klasiskal. Data survei menunjukkan bahwa sebagian besar siswa melaporkan "sangat puas" dengan sistem online. Selanjutnya, lembaga penyelenggara pendidikan yang mengimplementasikan media, sangat penting mendorong pendidik maupun peserta didik untuk menggunakannya. Oleh sebab itu, penting jika dunia pendidikan mengembangkan media pembelajaran berbasis google classroom untuk medukung kebijakan nirkertas dan penerapan teknologi media pembelajaran yang memenuhi kebutuhan revolusi industri 4.0.

\section{METODE PENELITIAN}

Pelaksanaan penelitian ini didasarkan pada metode Waterfall model (Pfleeger: 2006). Alasan menggunakan metode ini adalah karena metode waterfall melakukan pendekatan secara sistematis dan berurutan dalam membangun suatu sistem. Metodologi paling populer untuk mengembangkan perangkat lunak untuk sistem informasi berbasis komputer adalah metode waterfall (Youssef: 2012). Hal itu juga sesuai pendapat Adetokunbo (2013), metode waterfall menggunakan pendekatan linier dan sesuai untuk desain prosedural.

Metode waterfall fokus pada pengerjaan suatu sistem yang dilakukan secara berurutan. Sistem yang dihasilkan akan dapat dipertanggungjawabkan, karena dilaksanakan secara bertahap sehingga tidak terfokus pada tahapan tertentu. Mall (2003) berpendapat bahwa metode waterfall memiliki tahapan seperti pada Gambar 1.

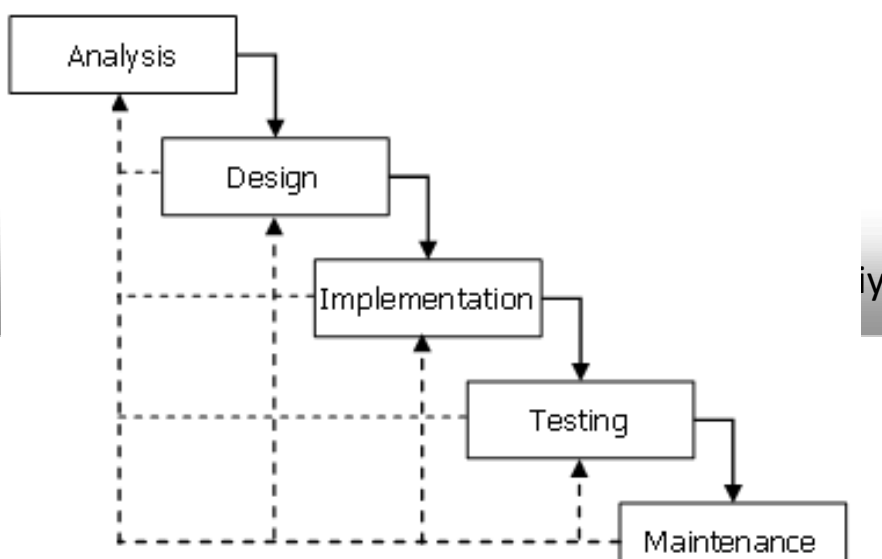




\section{Gambar 1. Metode waterfall}

1) Analisis kebutuhan

Diperlukan media yang dapat menyampaikan materi, diskusi, dan ujian dimanapun dan kapanpun. Layanan sistem dan tujuan ditetapkan oleh hasil konsultasi dengan beberapa dosen yang kemudian dinterpretasikan dalam bentuk menu, sub menu pembelajaran, diskusi dan ujian soal berfungsi sebagai spesifikasi sistem.

2) Desain sistem

Tahapan desain sistem menetapkan kebutuhan sistem baik hardware maupun software dengan merencanakan bentuk sistem secara keseluruhan. Perancangan perangkat lunak melibatkan identifikasi dan penggambaran sistem dasar perangkat lunak dan hubungannya.

3) Implementasi

Pada tahap ini, hasil perancangan desain direalisasikan sebagai serangkaian unit program atau sub unit program. Pengujian melibatkan verifikasi bahwa setiap unit memenuhi spesifikasinya.

4) Uji coba 
Bagian dan sub bagian yang sudah dibuat diuji sebagai sebuah sistem lengkap untuk memastikan kesesuaian dengan kebutuhan materi mata kuliah. Setelah pengujian, media diujicobakan ke mahasiswa.

5) Perawatan

Media google classroom perlu di selalu diperiksa kinerjanya dengan memerikasa dari keberadaan akun baik pendidik maupun peserta didik yang mengikuti perkuliahan.

Penelitian ini fokus pada media google classroom. Google classroom adalah aplikasi yang dibuat oleh google yang bertujuan untuk membantu dosen dan mahapeserta didik apabila kedua hal tersebut berhalangan, mengorganisasi kelas serta berkomunikasi dengan mahasiswa tanpa harus terikat dengan jadwal kuliah di kelas.

Perancangan media pembelajaran dilakukan dengan membuat google classroom di laboratorium komputer Jurusan Teknik Mesin. Tahapan pengembangan dilakukan dalam beberapa tahap untuk mempermudah dan memperjelas arah penelitian. Tahapan awal adalah analisis, orientasi produk adalah hasil perkembangan teknologi yang dapat dimafaatkan untuk evaluasi pembelajaran yaitu produk media pembelajaran berbasis google classroom yang nirkertas, berkualitas, menarik, dan mudah digunakan. Selanjutnya, desain media pembelajaran dilakukan dengan cara membuat konsep ujian dengan pilihan penggunaan google form yang diintegrasikan ke dalam sistem google classroom. Adapun jenis ujian yang digunakan adalah pilihan ganda (multiple choice). Pada tahap implementasi, dilakukan pembuatan sistem google classroom terutama pada menu pembuatan tugas kuis dengan syarat memiliki akun gmail.

Pengujian produk pada sampel yang terbatas menunjukkan bahwa kinerja sistem kerja baru ternyata yang lebih baik dari sistem lama. Setelah pengujian terhadap produk dinyatakan berhasil, maka selanjutnya produk yang berupa sistem kerja baru tersebut diterapkan dalam kondisi nyata untuk lingkup yang 
luas yaitu pada mata kuliah di lingkup jurusan Teknik Mesin Universitas Negeri Semarang sejumlah 30 mahasiswa. Dalam uji coba operasi sistem kerja harus dinilai kekurangan atau hambatan yang muncul guna untuk perbaikan lebih lanjut.

Selanjutnya, pengembangan melalui tahapan perawatan dengan melakukan revisi produk, apabila dalam perbaikan kondisi nyata terdapat kekurangan. Dalam uji pemakaian, sebaiknya pembuat produk selalu mengevaluasi bagaimana kinerja produk dalam hal ini adalah sistem kerja.

\section{HASIL PENELITIAN DAN PEMBAHASAN}

Pada tahap awal, dilakukan analisis kebutuhan media pembelajaran. Hasil analisis menunjukkan perlu sistem yang mempermudah penguji menyampaikan soal dengan mudah dipergunakan baik oleh penguji maupun peserta ujian, sesuai perkembangan jaman, dan dapat membuat berbagai jenis soal. Salah satu sistem yang dapat memenuhi kebutuhan di atas adalah google classroom.

Desain sistem menyesuaikan kebutuhan jenis ujian Pembuatan media CMS berbasis google classroom dengan mengisi data yang ditanyakan saat pertama kali masuk website google classroom. Sebelum memulai menggunakan google classroom terlebih dahulu mengakses website google classroom sesuai gambar 2.

Proses pembuatan pertanyaan sangat mudah. Langakh awal yang harus dilakukan adalah pilih create question. Terdapat beberapa jenis pilihan soal, misalnya soal essay dengan jawaban singkat (short answer) dan soal pilihan ganda (multiple choice) sesuai gambar 5.

$\equiv$ Google Classroom
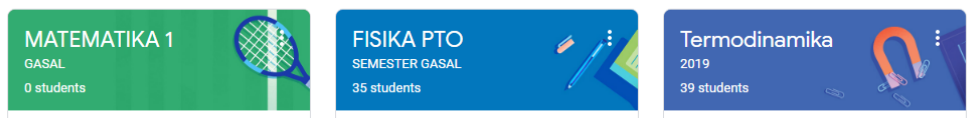
Gambar 2. Tampilan muka google classroom

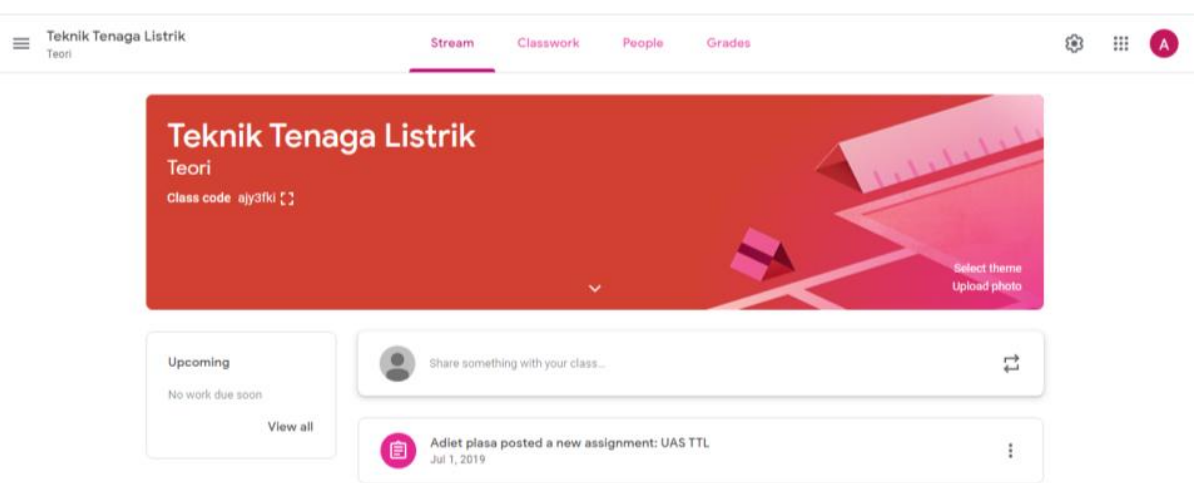

Gambar 3. Tampilan kelas teknik tenaga listrik dalam google classroom

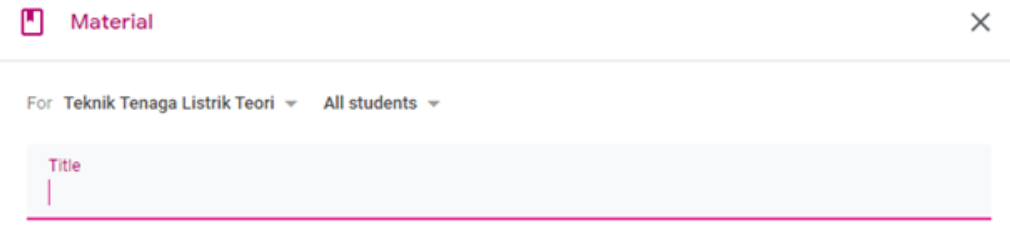

Description (optional)

Topic No topic

(i) 2 도

I0

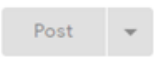

Gambar 4. Form materi kuliah teknik tenaga listrik 


\section{Gambar 5. Membuat quiz/ujian}

Implementasi soal dilaksanakan dalam proses ujian. Hasil proses pengerjaan soal dapat dilihat melalui menu responses, peserta yang sudah mengerjakan dan peserta yang belum mengerjakan soal tersebut beserta jawaban peserta. Setelah tugas terakumulasi, penguji dapat mengoreksi dan memberikan skor atas soal yang telah dijawab, sesuai gambar 6 .

Penguji dapat melihat kemajuan pekerjaan peserta ujian dalam google classroom dan menambahkan komentar atau melakukan pengeditan. Saat ujian selesai, penguji dapat memberikan nilai. Setelah memberi nilai, peserta ujian menerima pemberitahuan melalui email bahwa pekerjaan telah dikoreksi oleh penguji. Pekerjaan peserta ujian dapat dilihat, masuk ke tab tugas peserta kemudian pilih nama peserta yang akan diperiksa tugas/ujiannya.

Pemberian nilai, penguji harus memberi batasan sekor maksimal. Secara default google classroom menetapkan sekor 100, untuk mengubah pilih nilai kemudian tentukan sekor maksimal yang diinginkan, sesuai gambar 5 . Kemudian jika sekor sudah ditetapkan, pengisian nilai kepada mahasiswa untuk tugas/quiz tersebut dapat dilakukan dengan cara mengisi kolom nilai yang berada di samping nama mahasiswa/peserta.

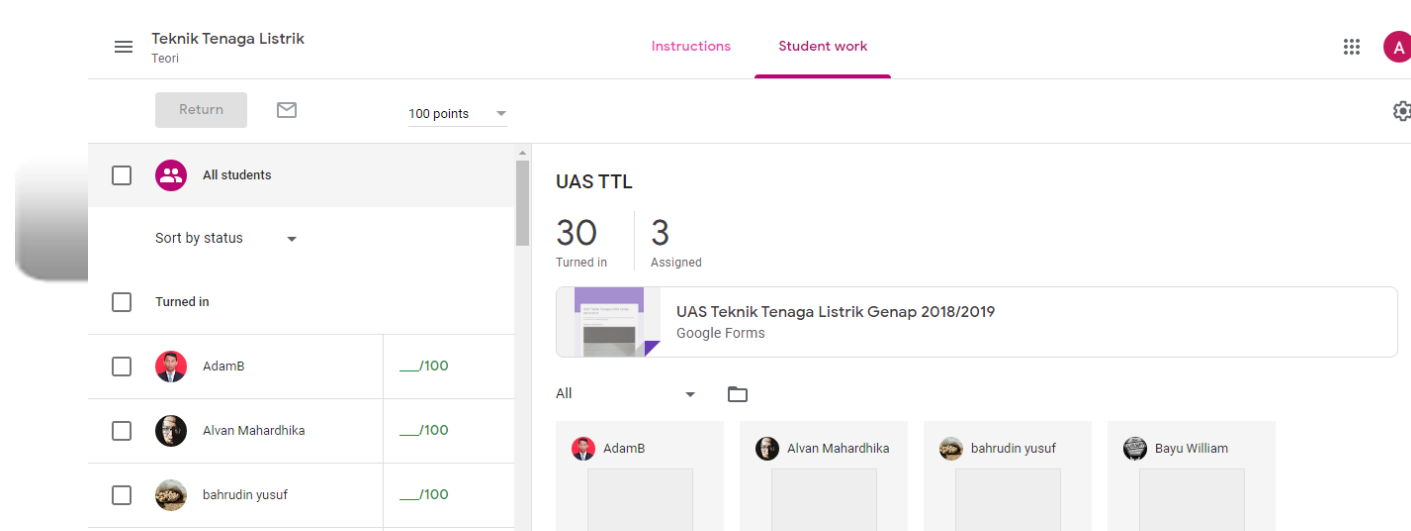


Gambar 6. Memilih tugas/ujian yang akan dikoreksi

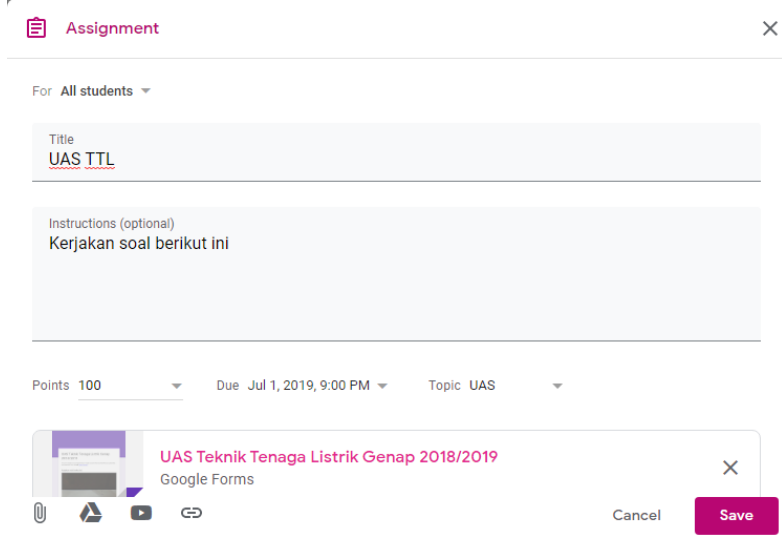

Gambar 7. Mengatur sekor quiz

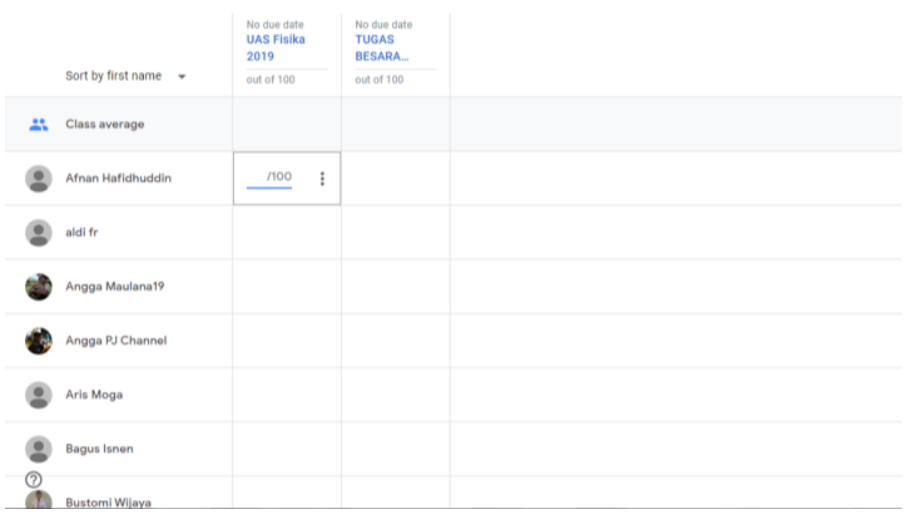

Gambar 8. Pemberian sekor peserta didik 
Kemudahan dalam mengelola hasil ujian juga diberikan oleh google classroom. Jika ingin mengunduh dan menyimpan nilai tugas sebagai data, klik pada simbol gear kemudian pilih apakah ingin mengunduh satu persatu nilai tugas atau mengunduh semuanya sekaligus.

Setelah diterapkan didapatkan hasil bahwa sistem secara keseluruhan dapat berfungsi dengan baik, dari menu, sub menu, tampilan soal, dan pemberian sekor berfungsi dengan baik. Keterbatasan terdapat pada penggunaan akun gmail, dapat terkunci jika akun terafiliasi langsung dengan instansi tertentu. Oleh sebab itu, sebaiknya menggunakan akun gmail.com ataupun gmail.co.id untuk penggunaan google classroom di Indonesia.

\section{SIMPULAN DAN SARAN}

Simpulan hasil penelitian ini adalah media pembelajaran berbasis google classroom yang diterapkan secara keseluruhan dapat berfungsi dengan baik, dari fungsi menu, sub menu, tampilan soal, dan pemberian sekor berfungsi dengan baik.

Saran dari penelitian ini sebaiknya menggunakan akun gmail.com ataupun gmail.co.id untuk penggunaan google classroom di Indonesia dan perlu perawatan sistem dengan melakukan pemeriksaan secara berkala baik isi materi maupun akun yang terdaftar di sistem.

\section{DAFTAR PUSTAKA}

Abdullah Alqahtani. 2019. Usability Testing of Google Cloud Applications: Students' Perspective. Journal of Technology and Science Education, vol 9, No 2019, http://www.jotse.org/index.php/jotse/article/view/585/414.

Adetokunbo A.A. Adenowo, Basirat A. Adenowo. 2013. Software Engineering Methodologies: A Review of the Waterfall Model and ObjectOriented Approach. International Journal of Scientific \& Engineering Research, Volume 4, Issue 7, July-2013, page 427-434.

Eros DeSouza. 2003. A comparison of in-class and online quizzes on student exam performance. Journal of Computing in Higher Education, March 2003, Volume 14, Issue 2, page 121-134.

Hendry Praherdhiono. 2019. Teknologi pada Media Pembelajaran. Diunduh dari https://teknologipendidikan.org/teknologi-pada-media-pembelajaran-2/, diakses pada 1 Desember 2019.

Jurnal Pendidikan Teknik Otomotif_Universitas Muhammadiyah Purworejo 
Mall, R. 2003. Fundamentals of Software Engineering. Prentice -Hall of India Private Limited. New Delhi.

Pfleeger, S.L. \& Atlee, J.M. (2006). Software Engineering: Theory and Practice, 3rd Edition. US: Prentice Hall. 